\section{TATRA \\ MOUNTaiNS \\ Mathematical Publications}

DOI: $10.2478 / \mathrm{tmmp}-2013-0040$

Tatra Mt. Math. Publ. 56 (2013), 1-25

\title{
FOUR DECADES OF CZECH AND SLOVAK NUMBER THEORY CONFERENCES
}

\author{
ŠTEFAN PORUBSKÝ
}

\begin{abstract}
The paper contains a short prehistory and history of the Czech and Slovak international number theory conferences.
\end{abstract}

When the author of these lines became a freshman of the Faculty of Natural Sciences of the Comenius' University to Bratislavd 1 in the winter semester 1966 , the math departments of the Faculty were located in a relatively new concrete building in the yard of a complex of older buildinge 23 on the today no more existing Šmeralova street under the castle. Actually there was only a small number of class rooms for small classes or lectures for students of higher semesters, and

(C) 2013 Mathematical Institute, Slovak Academy of Sciences.

The author was supported by the long-term strategic development financing of the Institute of Computer Science (RVO:67985807).

${ }^{1}$ Comenius' University was constituted on July 11, 1919 under the name Czechoslovak State University in Bratislava. On November 11, 1919 it was renamed as Comenius' University, which name it holds up to now with the exception of the period 1939-1954 when its name was Slovak University. The Faculty of Natural Sciences was constituted in 1940, but mathematics, physics and chemistry were lectured at the beginning by the members of the corresponding departments of the Slovak Technical University. Own Department of Mathematics of the Faculty of Natural Sciences was established in 1944.

${ }^{2}$ More precisely, the old building (cf. Fig. 1) on Šmeralova street (originally Kozia Street) was build in 1894 for a county court. In 1939 a secondary school moved in the building, and later physics, chemistry and mathematics of the Faculty of Natural Sciences. In 1960-61 a new building for mathematics was build in the yard. The new building stood, by the way, on the site of the medieval city place of execution outside the city walls, in front of St. Michael's Gate (where the city executioner lived) and coincidentally in the yard of the county court where the already demolished jail was located in the first third of the 20th century. Prof. Šalát sarcastically commented these facts by the words: "the effect remained, only the victims and the methods have changed", having figuratively the students and exams in mind. This complex was demolished about 1975. The math departments moved to a new campus in Mlynská dolina in 1972. Note that one of the major problems of the Faculty were premises where the departments resided. In the early sixties, the 32 departments of the Faculty were scattered through 25 distinct sites of the city. (The first and the last pictures are retrieved from http://ba.foxy.sk/displayimage.php?pid=1472 and http://www.bratislava.sk/vismo/galerie3.asp?id_org=700000\&id_fotopary=8005\&p1=53195, respectively, while the second and the third picture is taken by Ing. Rudolf Janík a former member of the Department of Nuclear Physics.) 


\section{ŠTEFAN PORUBSKÝ}

the building served mainly as an office building for the math faculty. The big main lectures and classes during the first 4 semesters were held on several more or less remote places scattered in the historical center of the city.
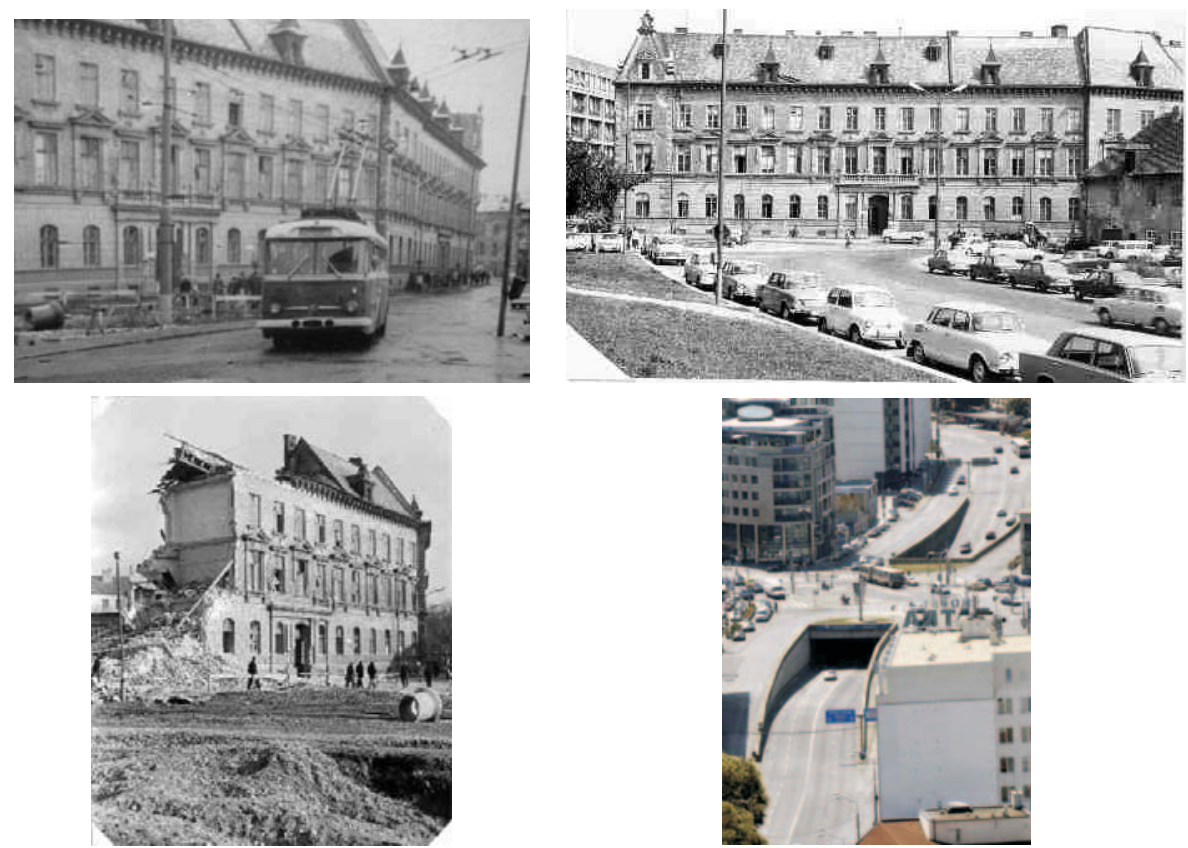

Figure 1. The metamorphoses of the old building in Šmeralova street. It stood approximately on the road bend in the right upper corner of the last picture and the new building before it.

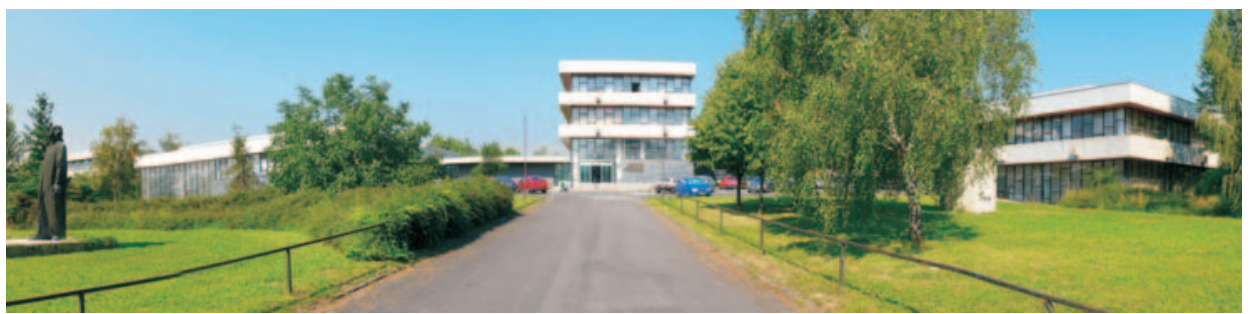

Figure 2. Faculty of Mathematics, Physics and Informatics of Comenius' University today on the campus in Mlynská dolina.

It is interesting to note that in Bratislava there was the only math department in the whole former Czechoslovakia that bore "number theory" in its name, 


\section{FOUR DECADES OF CZECH AND SLOVAK NUMBER THEORY CONFERENCES}

The Department of Algebra and Number Theory $3^{3}$ The Department detached from the original Department of Mathematics of the Faculty of Natural Sciences in 1964. This name gone back almost certainly to two important personalities of that time math life on the soil of the Faculty, two personalities who played an indisputable role on math scene not only in Bratislava but in the whole Slovakia at all, Prof. Milan Kolibiar [9, 10] who became its chair and Prof. Tibor Salát (cf. Fig. 31).

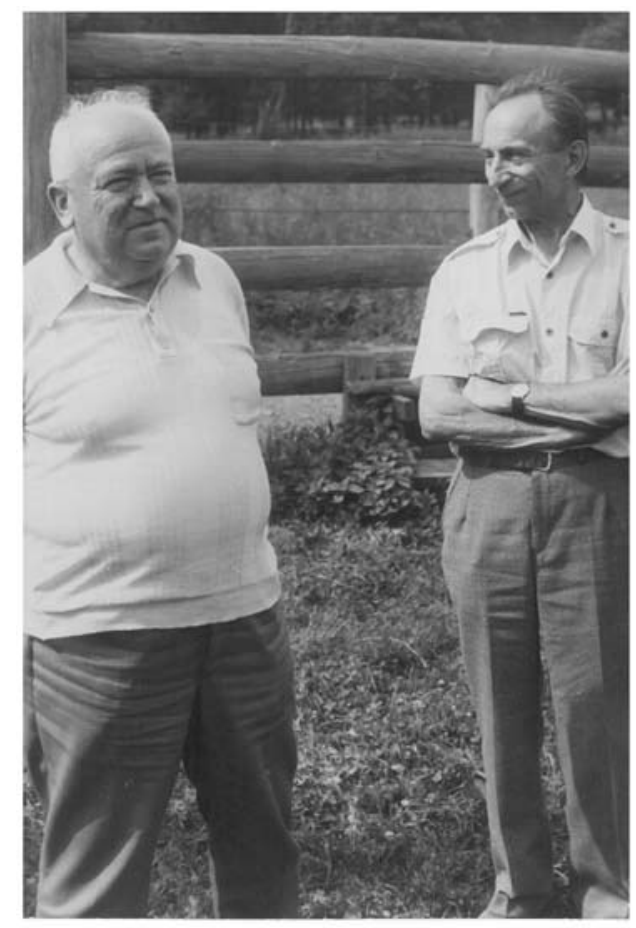

Figure 3. T. Šalát and M. Kolibiar.

\footnotetext{
${ }^{3}$ In $1978 / 79$ the Faculty of Natural Sciences had beside this 6 other departments: Department of Numerical Mathematics, Department of Mathematical Analysis, Department of Probability and Mathematical Statistics, Department of Theoretical Cybernetics, Department of Geometry, Department of Mathematics Education and Descriptive Geometry. To complete this picture it must be said that after splitting the Czechoslovakia on March 1, 1999 a Department of Algebra and Number Theory was founded on the Faculty of Natural Sciences of the Constantine the Philosopher University in Nitra, Slovakia, and its head was Prof. Vojtech László, a regular participant of the number theory seminar and the here described conferences till the nineties of the last century. On December 5, 2003 this Department was fused with Department of the Mathematical Analysis to one Department of Mathematics.
} 


\section{ŠTEFAN PORUBSKÝ}

The Czechoslovak number theory as such stood on the shoulders of three personalities:

- Matyáš Lerch (1860 - 1922) [17,18,

- Vojtěch Jarník (1897 - 1970) [14,

- Štefan Schwarz $(1914-1996) \sqrt{4}[14,20]$.

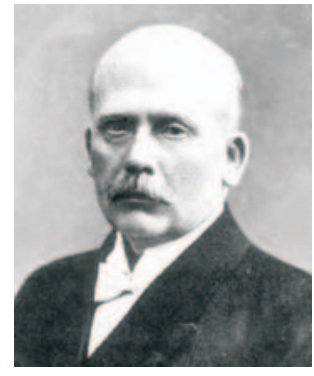

M. Lerch

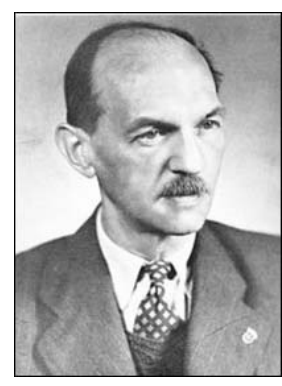

V. Jarník

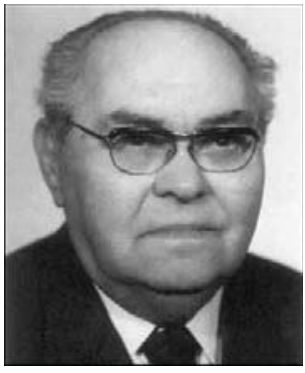

Š. Schwarz

Figure 4. The fathers of modern number theory in Czechoslovakia.

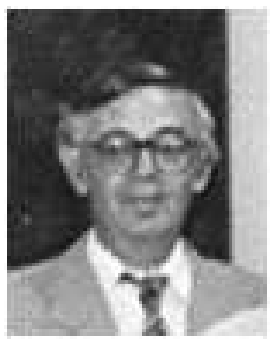

Š. Znám

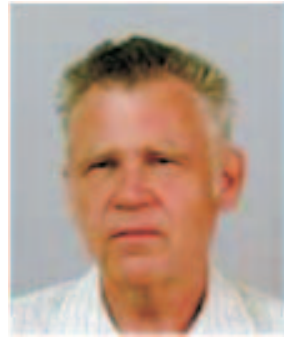

L. Skuła

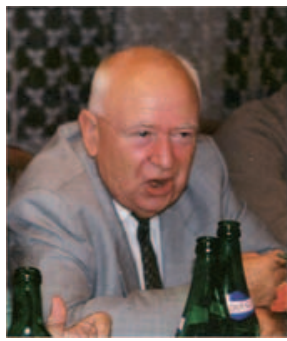

T. Šalát

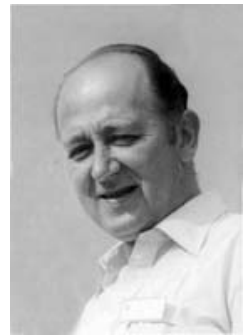

B. Novák

Figure 5. The initiators of the Czech and Slovak number theory conferences.

The first two of them, as it is well known, besides significant results from number theory also distinguished themselves in fields employing classical tools of the mathematical analysis, while the third one is known as one of the founders of the semigroup theory. Even if none of them left a real school of successors in number theory, the number theory persisted on the places of their activities. Let us mention Prof. Břetislav Novák [8] in Prague, Prof. Ladislav Skula in Brno and

\footnotetext{
${ }^{4}$ Actually the last PhD. student of Karel Petr (July 14, 1868 - February 14, 1950) a prominent Czech mathematicians of the first half of the 20th century and author of more than 100 papers from which 22 are devoted to number theory.
} 


\section{FOUR DECADES OF CZECH AND SLOVAK NUMBER THEORY CONFERENCES}

Prof. Tibor Šalát in Bratislava as representatives of the centers of number theory from the period of the first two decades of the existence of the Czech and Slovak International Conferences on Number Theory.

T. Šalát (May 13, 1926 - May 14, 2005), a graduate of the Charles University in Prague, was strongly influenced during his study there by Eduard Čech, Miloš Kössler and mainly by Vojtěch Jarník. Consequently his main interests appertain to theory of real functions and number theory. Prof. Šalát led with the help of his close friend Tibor Neubrunn [19, probably from the year 1964, a seminar devoted to theory of the real functions and the measure theory. This seminar split later in the second half of sixties into two ones, one devoted to the theory of real functions and the second one to the measure theory. The first one remained under the auspices of Tibor Šalát, the second one was led by Tibor Neubrunn. There are indications that it was Tibor Neubrunn who came with the idea to organize meetings of the seminars in forms of several days workshops outside the city. This opened a tradition of the so-called summer schools on the theory of real functions which later become a known international event, a model which later followed also the number theory 5

In general it can be said that the sixties were a breeding-ground for the Prague spring '68. In mathematics the atmosphere reflected by a growing number of international and national conferences on various subjects. Let us mention at least the following ones having some personal or topical intersections with the number theory scene:

- Symposium on Graph Theory and Its Applications, organized by the Mathematical Institute of the Slovak Academy of Sciences and the Mathematical Institute of the Czechoslovak Academy of Sciences, June 17-20, 1963. It was the world's first international conference on the subject with participants from both sides of the iron curtain with 24 Czechoslovak and 13 foreign participant: 6 .

\footnotetext{
${ }^{5}$ It seems that the first who organized such a series of workshops called summer schools was Prof. Kolibiar who organized them on partially ordered sets and universal algebra every year since 1962. Actually, these summer schools were held every year alternately in Slovakia and Moravia. If the school was in Slovakia the main organizer was Prof. Kolibiar and in the case of Moravia it was Prof. Novotný (possibly with prof. Šik). The original subject of the summer schools were partially ordered sets endowed by a topological structure. The transition to the universal algebras appeared later (1966), and since then the summer schools focused mainly on universal algebra. An important figure behind this summer schools was Professor Josef Novák a participant of the famous Čech's pre-war topological seminar in Brno.

${ }^{6}$ For instance, G. A. Dirac, P. Erdôs, M. Fiedler (read [7] how a numerical algebraist came to graph theory), T. Gallai, F. Harary, A. Kotzig, G. Ringel, C. St. J. A. Nash-Williams, A. A. Zykov, etc.
} 


\section{ŠTEFAN PORUBSKÝ}

- Symposium on Graph Theory and Combinatorial Analysis, organized by the Mathematical Institute of the Slovak Academy of Sciences and the Mathematical Institute of the Czechoslovak Academy of Sciences, June 14-17, 1966 with 51 participants.

- Symposium on Graph Theory and Combinatorial Analysis, organized by the Mathematical Institute of the Slovak Academy of Sciences and the Mathematical Institute of the Czechoslovak Academy of Sciences, June 26-29, 1969 with 52 participants.

- Symposium on Semigroup Theory and Its Applications, organized by the Mathematical Institute of the Slovak Academy of Sciences, June 17-22, 1968. It was the world's first international conference on the subject with 24 Czechoslovak and 37 foreign participants.

All of these four symposia took place in the Smolenice castle, the Congress Center of the Slovak Academy of Sciences.

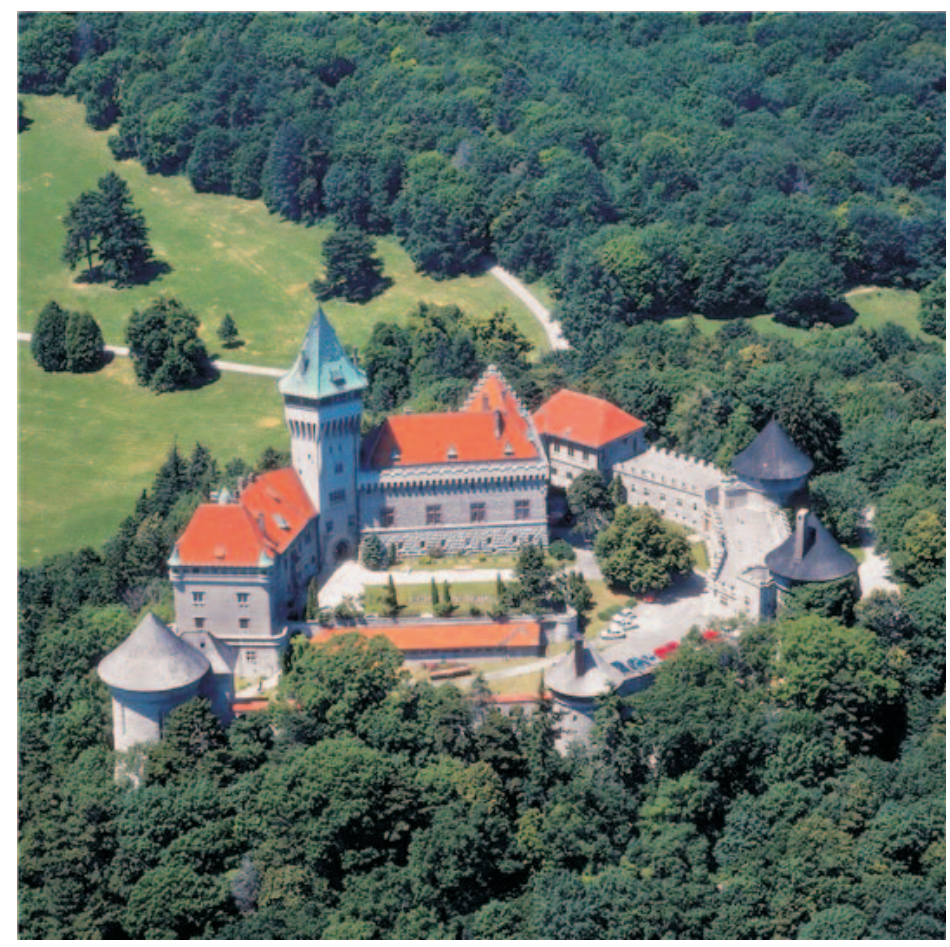

Figure 6. Congress Center of the Slovak Academy of Sciences in Smolenice.

At that time the standard Central European system of academic and scientific degrees which was valid till beginning of the 50ties was strongly deformed 
by eastern Russian influence. The doctoral degrees prior to these changes were based on the medieval tradition of "doctorates" and the university graduates were not awarded any degree after their state exams. In Czechoslovakia as a former part of the Austrian-Hungarian Empire the educational system and the corresponding system of scientific degrees corresponded to the standards as we know them from Austria or Germany. It originated in the Education Act from April 15, 1872, No. 57/1872 of the Ministry of Culture and Education of the Austrian Empire. After creation of Czechoslovakia in 1918, in 1920 the philosophical faculties were generally divided into two parts: the philosophy faculty and the faculty of natural sciences, and so the degree $\mathrm{PhDr}$ still valid for philosophical sciences obtained an analogue RNDr (rerum naturalium doctor) for natural sciences. This was then changed by the communistic government by the Education Act No. 58 from the year 1950 with the operation from the year 1953. This law introduced a Russian system of degrees. The Russian equivalent of the PhD was translated as the CSc degree (from Latin candidatus scientiarum, Candidate of Sciences). The originally to it corresponding degrees like PhDr or RNDr were abolished.

Prof. Šalát was an engaged and enthusiastic teacher. He supervised 8 PhD students: Jaroslav Smítal (1972), Pavel Kostyrko (1972), Anna Neubrunnová (1974), Vojtech László (1979), Oto Strauch (1980), Jozef Doboš (1986), Ján Borsík (1987) and Milan Paštéka (1992). Three of them (VL, OS, MP) worked mainly in number theory, one $(\mathrm{PK})$ partially and rest of them mainly in the theory of real functions and related topics. Five of them (JS, PK, VL, OS, MP) actively participated on the number theory conferences and their organization at least at the beginning of their career.

The social situation changed slightly after the new Higher Education Act of 1966 reintroduced the title RNDr in a new form. Not as the highest academic and scientific award, since these have been introduced as mentioned by the still valid Soviet model of scientific degrees. Technically it became a post-graduate academic degree awarded by universities, and was always written before names. It was awarded after the graduate defended a written work and passed a rigorous examination of the chosen scientific discipline and the broader scientific base. It become popular as the "little doctorate", in contrast to the degree "Doctor of Sciences" DrSc (doctor scientiarum), called the "big doctorate" and not existing in the portfolio of scientific degrees prior to changes in 19537

The revival of the degree RNDr, even in its changed role, was a part of the efforts to uplift the lost social status of the middle layer, strong devastated by the persecutions in the fifties. One eminent part of the middle layer were secondary school teachers, whom social status was greatly deformed not only by

\footnotetext{
${ }^{7}$ Granting of CSc was abolished in Czech Republic in 1998 and in Slovakia in 1996 and in both countries it was replaced by $\mathrm{PhD}$. Granting of the degree $\mathrm{DrSc}$ was abolished only in the Czech Republic namely in 2001.
} 


\section{ŠTEFAN PORUBSKÝ}

Stalinist persecutions in the fifties, but also by hasty changes in school rules and an expansive introduction of new secondary schools. The starting political liberalization at the beginning of the sixties partly caused an activation of the secondary schools teachers with the aim to introduce changes returning the teachers their old status. So Prof. Šalát opened a preparatory seminar for more ambitious secondary school teachers and young university assistants. His intension was to create a stimulation for a research activity among the secondary school teachers, which motivation for an individual scientific activity (a standard in the prewar times) was negatively influenced by stalinist system and its aftermath. As a basis served mainly W. Sierpiǹski's books, which were more or less easily accessible. This selection was mainly due to the fact that as written in Polish they were readable for the relative Slavic language Slovak, especially for generations which in schools learned Russian as an only foreign language after WWII. These books were complemented by reading of suitable original papers mainly from elementary and analytic number theory, and by solutions of adequate open problems or problems published in journals like The American Mathematical Monthly. Later the book by I. Niven and H. Zuckerman was read 8

The seminar started to work sometimes in autumn 1968 and took place in today's building of the Faculty of Architecture of the Slovak Technical University on at that time called Gottwald's square (today The Square of Freedom) 9 . In that time it was the building of the so-called theoretical departments of the Slovak Technical University 10 . Here was also located the common Department of Mathematics for the Slovak Technical University established after a reorganization of the University in 1950. Formally it was incorporated into the structure of the Faculty of Electrical Engineering. Its head was Stefan Schwarz 11

\footnotetext{
${ }^{8}$ A typical output of the seminar was, e.g., the paper [11.

${ }^{9}$ Klement Gottwald was the first communist president of Czechoslovakia. The square was familiarly called by its old name "Firšnál" at that times, because the new names given to streets and squares in communist period were not popular. This still living vernacular name garbled from old German name "Fürstenallee" meaning "Duke Alley". The reason for this name was the fact that on one of the square sides there was the former archbishop's summer palace (today the residency of the office of the Slovak government) with a big park and alleys. The archbishop of Esztergom, Primate of Hungary, owner of these residences, automatically gained the rank of a duke, even if he did not come from a noble family. Note that Esztergom was the first capital of Hungary, and Bratislava was its capital from 1536 for 150 years during partial Ottoman occupation of the Hungary. Eleven Hungarian kings and queens were crowned in Bratislava between 1536 and 1830. Archbishop moved definitely back to Esztergom at the beginning of 19th century. Also the sessions of the Diet of Hungary (originally Parlamentum Publicum or Parlamentum Generalye) were primarily held in Bratislava since the 18th century. For instance, the Hungarian Academy of Sciences (the Learned Society) was also founded here during its session in 1827 .

${ }^{10}$ Pavilón teoretických ústavov SVŠT (in Slovak).

${ }^{11}$ In 1961 there detached separate departments of mathematics of the remaining faculties of the Slovak Technical University from it.
} 


\section{FOUR DECADES OF CZECH AND SLOVAK NUMBER THEORY CONFERENCES}

This venue was probably selected because of a good position of the building and due to appropriate rooms for seminars.

The participants of the seminar came from the Faculty of Education in Nitra (Vojtech László)12, Faculty of Education in Trnava (Július Bačík, Hanzalík, Eva Nyulassyová) and from the faculties of the Slovak Technical University (K. Košuk) besides participants from the Faculty of Natural Sciences (Elena Bereková, Katarína Hajtášová, etc.). Several seminars organized outside Bratislava in these towns sown a seed of the future regular conferences.

It is very probable that the idea of number theory conferences loomed in the head of Prof. Tibor Šalát from the very beginning, but it was not sufficiently shored personally. It is almost certain that number theory related lectures were delivered already on the mentioned summer schools on the theory of real functions. Atmosphere slowly changed after Štefan Znám's [16] transfer from the Department of Mathematics of the Faculty of Chemical Technology of the Slovak Technical University to the Department of Algebra and Number Theory of the Faculty of Natural Sciences in 1968 when he joined the seminar on the theory of numbers. He brought another element in it because he mainly focused on problems of combinatorial nature. So for instance, in number theory he solved the so called Mycielski's problem on arithmetic sequences, problems on $k$-thin sets at that time. But also some others problems of combinatorial character (e.g., Zarankiewicz' problem) or problems in graph theory (e.g., decomposition of complete graphs into factors with given diameter). In 1969 he also took over together with Juraj Bosák [25] the leadership of the Bratislava graph theory seminar after Anton Kotzig [3] left for Canada.

Štefan Znám was with a great probability the main mover behind the zeroth conference of the later arising series of conferences on number theory. It was held from May 25 till May 29, 1970 in the schooling facility of the Comenius' University near Bratislava in Modra - Harmónia. Its name was The Summer School on Number Theory and Graph Theory and it was organized under the auspice of the Union of Slovak Mathematicians and Physicists. There were two foreign participants János Surányi and Vera Turán-Só 13 from Budapest.

The definite impetus to the conferences on number theory gave the opening of the building for mathematics in the new campus of the Faculty of Natural Sciences in Mlynská dolina where the mathematics moved in 1971-72 14 The seminar on number theory moved to the new building. Under these circumstances,

\footnotetext{
${ }^{12}$ The lists of names are by no means complete, the author was not able to complete them after the years.

${ }^{13}$ By the way, independently of this in the period October $17-21$ there was as a guest of the Slovak Academy of Sciences her husband Prof. Pál Turán in Bratislava.

${ }^{14}$ The works on the new campus started in 1967 and in the subsequent years 1967-1978 pavilions for mathematics, computer center, physics, chemistry and biology were build. Another significant change for mathematics as such brought the year 1980 when a separate
} 


\section{ŠTEFAN PORUBSKÝ}

the first of the future series of conferences was organized. It venue was the schooling center of Comenius's University in Lubochňa 15

This is the list of the hitherto organized conferences on number theory:

- September 11-15, 1972, Summer School on Number Theory, Lubochn̆a, Czechoslovakia,

- September 15-19, 1975, Summer School on Number Theory, Kočovce, Czechoslovakia,

- October 3-7, 1977, Autumn School on Number Theory, Kočovce, Czechoslovakia,

- October 1-5, 1979, 4th Czechoslovak Number-theoretical Summer School, Čaradice, Czechoslovakia,

- October 5-9, 1981, Autumn School on Number Theory, Manětín u Plzně, Czechoslovakia,

- September 5-9, 1983, Summer School on Number Theory, Chlébské, Czechoslovakia,

- September 9-13, 1985, 7th Czechoslovak Colloquium on Number Theory, Pribylina in Račková dolina (High Tatras), Czechoslovakia,

- September 8-11, 1987, Autumn School on Number Theory, Teplýšovice u Prahy, Czechoslovakia,

- September 11-16, 1989, 9th Czechoslovak Colloquium on Number Theory, Pribylina in Račková dolina (High Tatras), Czechoslovakia,

- September 2-7, 1991, 10th Czechoslovak Conference on Number Theory, Mýto pod Duumbierom, Czechoslovakia,

- September 5-11, 1993, 11th Czech and Slovak International Conference on Number Theory, Račková dolina, Slovakia,

- September 4-9, 1995, 12th Czech and Slovak International Conference on Number Theory, Liptovský Ján (Hotel Ďumbier), Slovakia,

- September 1-5, 1997, 13th Czech and Slovak International Conference on Number Theory, Ostravice, Czech Republic,

- September 6-10, 1999, 14th Czech and Slovak International Number Theory Conference, Liptovský Ján (Hotel Ďumbier), Slovakia,

Faculty of Mathematics and Physics was established. In 2000 it changed name to Faculty of Mathematics, Physics and Informatics.

${ }^{15}$ Actually in the former communist regime, such centers played a double role. They were often a property of trade union organizations and they were predominantly used for recreational purposes of the university employees. Outside the holiday season they served as a venue of various training courses and conferences. 


\section{FOUR DECADES OF CZECH AND SLOVAK NUMBER THEORY CONFERENCES}

- September 3-8, 2001, 15th Czech and Slovak International Conference on Number Theory, Ostravice, Czech Republic,

- June 30-July 4, 2003, 16th Czech and Slovak International Conference on Number Theory, Bratislava, Slovakia,

- September 5-10, 2005, 17th Czech and Slovak International Conference on Number Theory, Malenovice, Czech Republic,

- August 27-31, 2007, 18th Czech and Slovak International Conference on Number Theory, Smolenice, Slovakia,

- August 31-September 4, 2009, 19th Czech and Slovak International Conference on Number Theory, Hradec nad Moravicí, Czech Republic,

- September 5-9, 2011, 20th Czech and Slovak International Conference on Number Theory, Stará Lesná, Slovakia,

- September 2-6, 2013, 21st Czech and Slovak International Conference on Number Theory, Ostravice (Hotel Sepetná), Czech Republic.

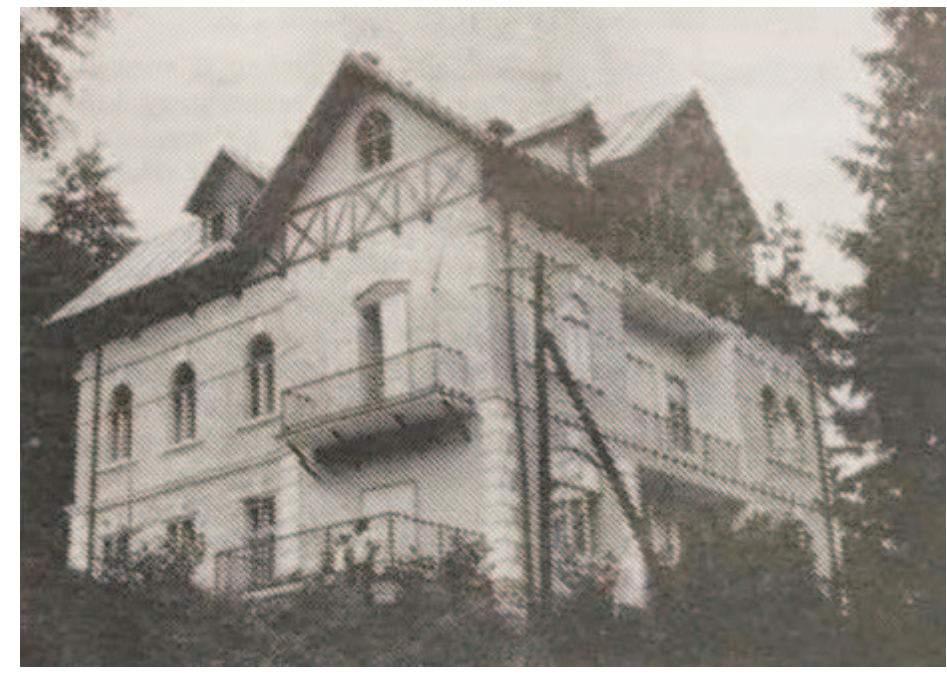

Figure 7. Schooling and recreational center of Comenius' University in Lubochňa in 1976.

Only few documents related to the first ten conferences survived. Most of them in private archives. The next facts are collected mostly from personal archives of V. László, L. Skuła, O. Strauch and K. Szymiczek. The first conference was held, as mentioned, in the Schooling and recreational center of Comenius' University in Lubochňa (Fig. (7). Beyond the participants of the Bratislava seminars on the theory of real functions and the theory of numbers, there were only two 


\section{ŠTEFAN PORUBSKÝ}

other participants: Ladislav Skula from Brno and Alois Apflebeck from Prague. Probably the most known output of the Lubochňa conference was a problem posed here by Štefan Znám and today known as Znám's problem (see [23]): Given $k$, find all sets of integers $\left\{n_{1}, \ldots, n_{k}\right\}$ all greater than 1 , such that $n_{i}$ is a proper divisor of $1+\prod_{j \neq i}^{n} n_{j}$ for each $i=1, \ldots, k 17$

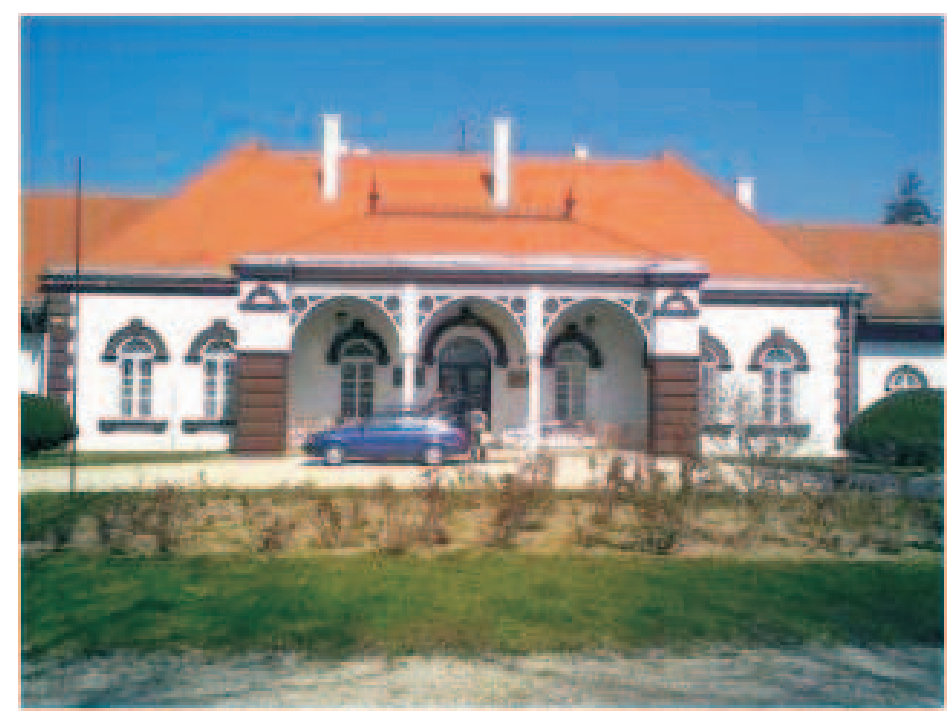

Figure 8. Schooling and recreational center of the Faculty of Civil Engineering of the Slovak University of Technology in Kočovce.

\footnotetext{
${ }^{16}$ Prof. Dr. Alois Apfelbeck (1925-1992) 12 was a fellow student of Tibor Šalát at Charles University in Prague. He was a regular participant of the conferences at the beginning and excelled by a specific and original type of humor. One of his typical stories: As many of the faculty of the universities at that time, he was also forced to pass a political schooling on the so called Evening University of Marxism-Leninism. The schooling finished with an exam. The examinator started the exam with a rhetorical question: "You are after all an older person as me. I'm almost feeling ashamed to exam you". Apfelbeck immediately replied: "Why should you feel ashamed, if you do not feel ashamed lecture about such things." (cf. http://km.fjfi.cvut.cz/o-katedre/historie retrieved December 29, 2013.) In Lubochn̆a he lectured about Collatz $3 x+1$ problem. By the way, he also translated Collatz's Funktionalanalysis und numerische Mathematik in Czech.

${ }^{17}$ A closely related problem, the so-called improper Znám's problem, was independently posed by G. E. J. Barbeau [5] around the same time. In this case $n_{i}$ is a divisor, but not necessarily a proper one. Actually, Barbeau had posed the improper Znám problem for $k=3$. Mordell [13] in reaction on Barbeau's problem found all solutions to the improper problem for $k \leq 5$. Skula 23] showed that Znám's (proper) problem is unsolvable for $k<5$, and credited J. Janák with the solution $\{2,3,11,23,31\}$ for $k=5$. It is unknown whether there are any solutions to Znám's problem using only odd numbers. With one exception, all known solutions start with 2. Consult, e.g., 6] for more details about this problem.
} 


\section{FOUR DECADES OF CZECH AND SLOVAK NUMBER THEORY CONFERENCES}

The influence of Štefan Znám manifested mainly as a booster of the idea to increase the prestige of the conferences by invitation of foreign mathematicians. In 1967 or 1968 he visited Gliwice and Katowice where he got acquainted with Kazimierz Szymiczek. A later byproduct of this his study journey to Poland was that K. Szymiczek 18 was the first foreign participant on these conferences. It happened already on the second conference in Kočovce in 1975 organized by T. Šalát and Š. Znám (even if Znám was not attending the conference itself). K. Szymiczek was the first and the only foreign participants on the first Kočovce conference in 1975. He contributed to the program of the conference with the lecture Ten problems from the algebraic theory of quadratic forms (cf. [24]). The next conference in 1977 was on the same venue, but this time with 3 foreign participants: K. Szymiczek, A. Schinzel and V. G. Sprindžuk 19 . The chairman of the organizing committee was Štefan Znám.

That these two conferences were held in Kočovce was the consequence of the fact that K. Košuk, a participant of the original preparatory seminar, was an assistant professor of the Department of Mathematics of the Faculty of Civil Engineering. It was a common practice at that time that the conferences were organized by a bootstrapping method, where participants of a seminar used their personal contacts with the authorities of their faculties to book a date in the education or recreational facilities. The same situation was with other conferences. For instance, the venue of the conferences in Račková dolina was the Teaching and training facility of the Slovak Agricultural University in Nitra20, where helped V. László and J. Bačík. It was the case of all the conferences organized up to the collapse of the communist regime and several years after it. For instance, the venue of first after velvet revolution conference in Mýto pod Dumbierom in 1991 was partly organized in this way, when the venue of the conference was the recreational facility of the trade union organization of the factory Mostáren Breznd 21 where the father-in-law of the author of this paper was employed.

The organizing committee in Čaradice was: Štefan Znám (chairman), Helena Bereková, Vojtech László, Oto Strauch, Štefan Porubský. From abroad came

\footnotetext{
${ }^{18}$ By the way K. Szymiczek was born in a Polish family in the mining town Petřvald (district Karviná), which lies in the Silesian part of the northern Moravia.

${ }^{19}$ V. G. Sprindžuk was actually a visiting professor at the Mathematical Institute of the Slovak Academy of Sciences in Bratislava at this time. The initiator of this invitation was Š. Porubský. Actually, the Mathematical Institute of the Slovak Academy of Sciences had at that time quite acceptable means to invite foreign mathematicians. For instance, the participation of R. Tijdeman in 1979, of A. Schinzel or W. Narkiewicz on several conferences, or W. Schwarz in 1989 etc. were supported in this way.

${ }^{20}$ Učebno-výcvikové zariadenie Vysokej školy polnohospodárskej v Nitre in Slovak.

${ }^{21}$ Production programme of no more existing factory Mostáren Brezno, but during the communist time having more than 2000 employees, was the development, production and sale of cranes and transport equipments and devices.
} 


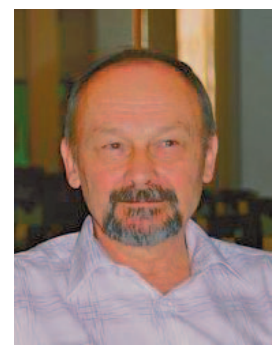

K. Szymiczek

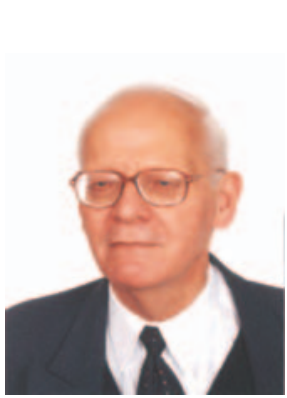

A. Rotkiewicz

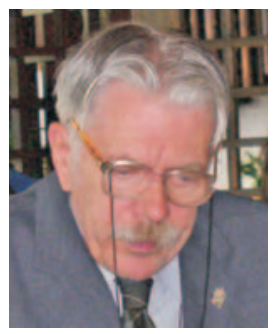

A. Schinzel

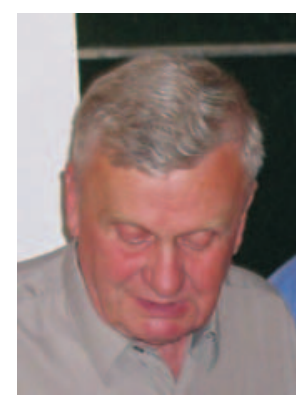

A. Mąkowski

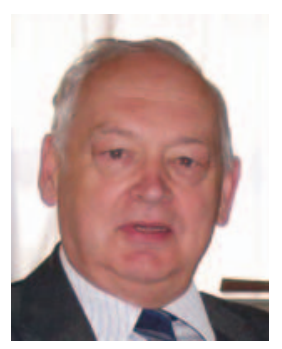

W. Narkiewicz

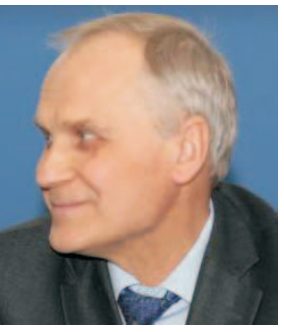

A. Czogała

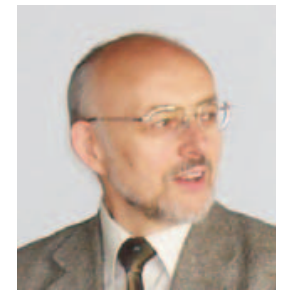

A. Sładek

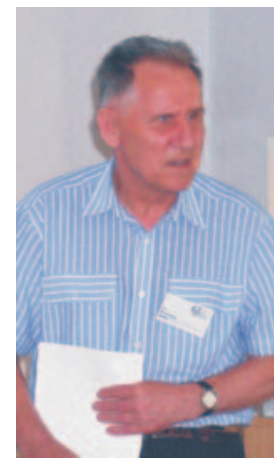

J. Krempa

Figure 9. The Polish connection.

A. Schinzel (Warsaw), W. Narkiewicz (Wrocław), and R. Tijdeman (Leiden). From three lectures of R. Tijdeman let us mention the talk devoted to F. Beukers' proof of the irrationality of $\zeta(3)$. J. Nešetřil took up on his lecture in Kočovce in 1977 where he presented three easy proofs of theorems on partitions of integers with the lecture on the joint work with V. Rödl on combinatorial properties of partitions of integers.

The Manětín autumn school was the first one in the series not organized by a participant of T. Šalát's seminar. It was organized by Břetislav Novák from Prague. The originally planned venue of the Autumn School on Number Theory in Manětín was the Conference center of the Czechoslovak Academy of Sciences in Alšovice. Due to its unanticipated reconstruction adaptations the venue was changed. This was actually the only conference on which the author of these lines did not attend. There were 17 participants on the conference with the only foreign mathematician E. Wirsing having a talk An analytic problem in connection with interval basis. 


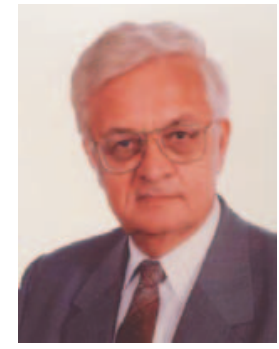

K. Györy

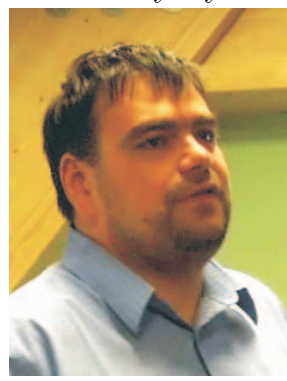

A. Bérczes

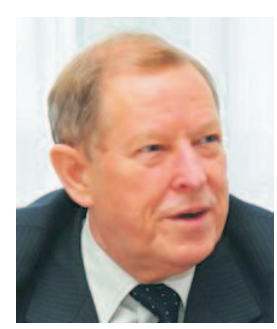

A. Pethő

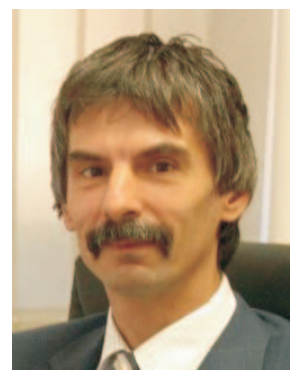

I. Gaál

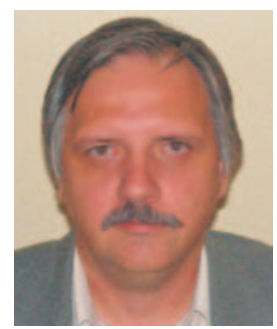

L. Hajdu

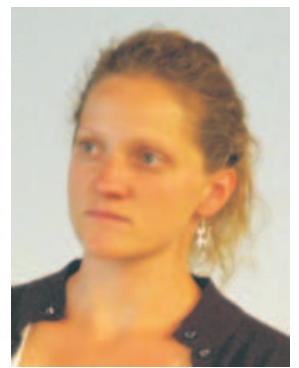

T. Kovács

Figure 10. The Debrecen connection.

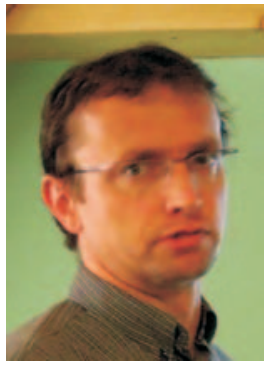

M. Bulant

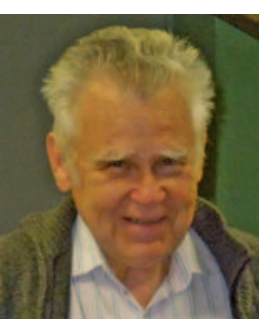

L. Skula

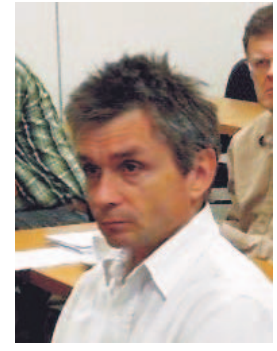

R. Kučera

Figure 11. The Brno team.

The conference in Chlébské was organized by L. Skula. The organizing committee was L. Skula (chairman), B. Novák (cochairman) and P. Horák (secretary), There were 20 participants, among them H. Koch (Berlin), K. Szymiczek and W. Więsław (Wrocław). For more information consult [22].

The main organizer of the conferences in Račková dolina 1985 was the author of these lines. He tried to change the by then used term "school" by one 


\section{ŠTEFAN PORUBSKÝ}

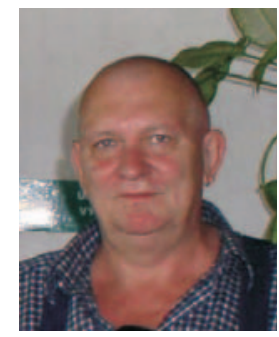

S. Jakubec

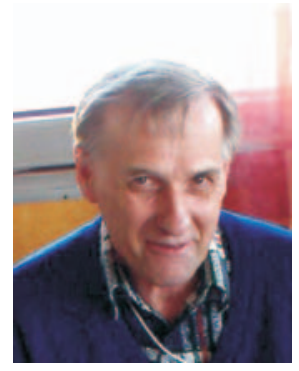

O. Strauch

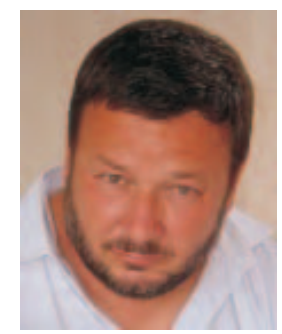

J. Tóth

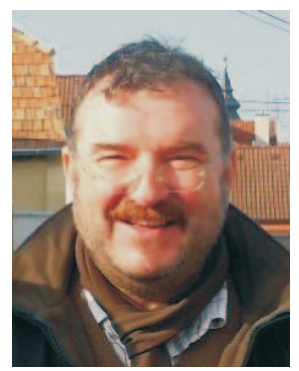

V. Baláž

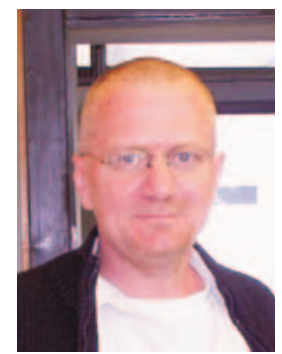

M. Paštéka

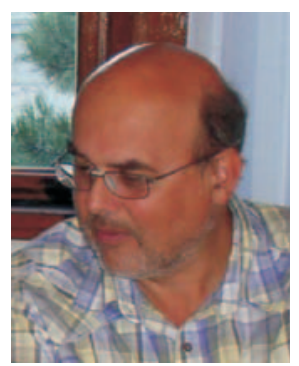

K. Nemoga

Figure 12. The Slovak team.

more characterizing the spirit of the conferences 22 , which convention was then definitely used after the political changes caused by the collapse of communism at the end of 1989. The velvet revolution also changes drastically the preprocesses for the formal preparations of the organization of a conference. In the communist era these procedures were partly different when a conference was organized by a department of a Faculty or by an institute of the Academy of Sciences. In the case of an involvement of a department of a university into an organization of a conference the role of communist party was more conspicuous. For instance, the 1985 conference in Račková dolina was coorganized by Oto Strauch at that time at the Faculty of Natural Sciences. On the Academy of Sciences, it was formally necessary to have only an approval of the so-called Scientific advisory board which members were mathematicians from various institutions and no written communication with party was necessary. Fig. 15 shows the required written approval letter of the organization of the communist party of the whole Comenius' University to organize a conference and containing the assertory list of the invited foreign participants and this even in the case that both invited speakers A. Schinzel and V. G. Sprindžuk were from the eastern block.

\footnotetext{
${ }^{22}$ The change of the name was not accepted consistently, see for instance, the first published proceedings [1 p. 195-300] of a conference in this series.
} 


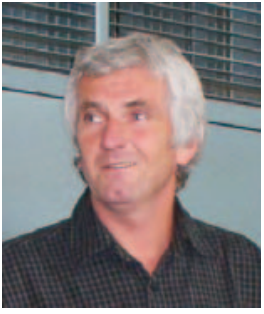

L. Mišík

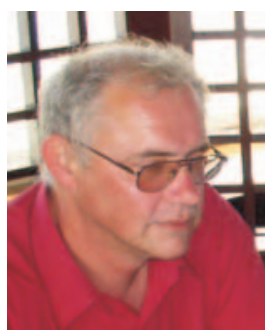

J. Kostra

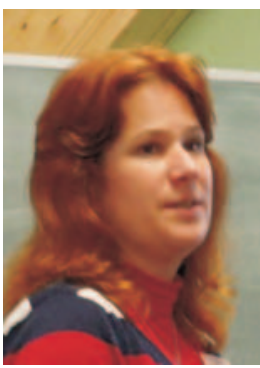

Z. Václavíková

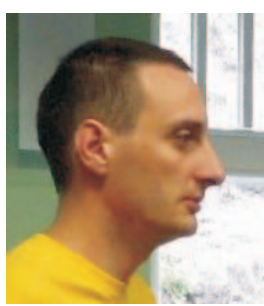

J. Šustek

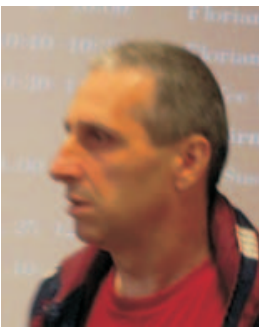

J. Hančl

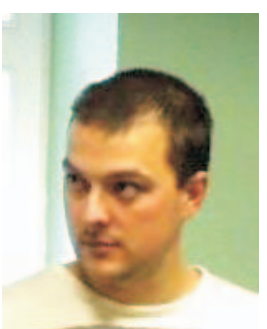

L. Novotný

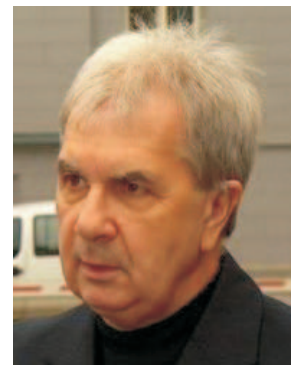

J. Močkoř

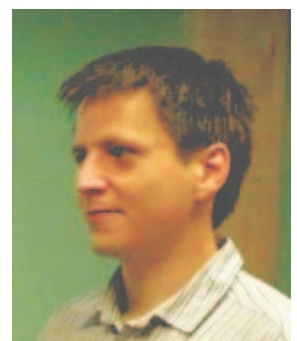

D. Krčmarský

Figure 13. The Ostrava team.

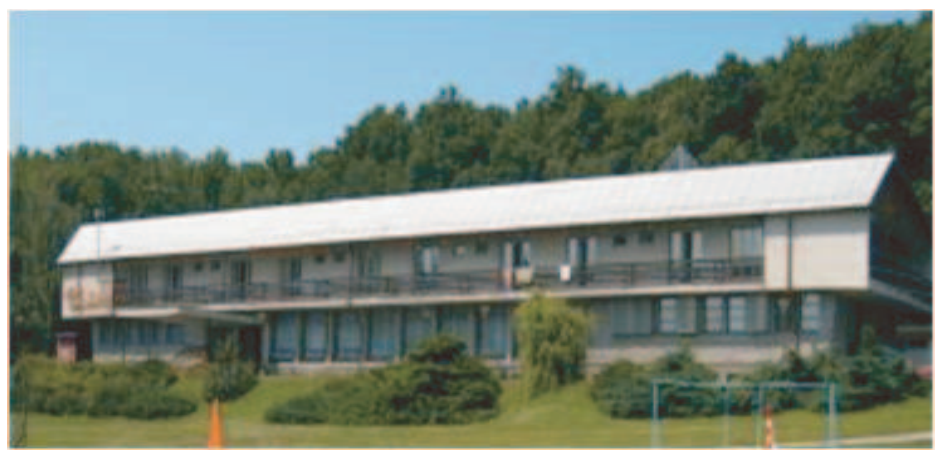

Figure 14. Recreational center of factory Calex in Caradice, the venue of the 4 th conference.

Only for information, the registration fee was approximately 25 West German marks, and board and logging for the whole conference 70 marks.

The conference in Teplýšovice was again organized by B. Novák. The first day was devoted to the 90th anniversary of Vojtěch Jarník birthday. It was celebrated by three lectures: M. M. Dodson (York) on Hausdorff's dimension, P. Gruber (Vienna) on lattice points, and D. Preis (Prague) on Dini's derivatives. 


\section{ŠTEFAN PORUBSKÝ}

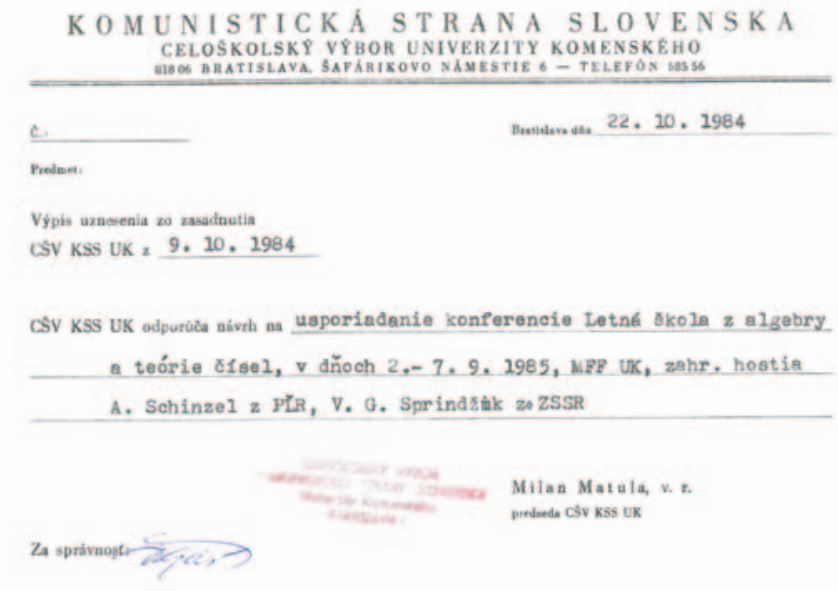

FiguRE 15. The written approval of the organization of the communist party of the Comenius' University to organize a conference with listed invited foreign participants.

This was probably the first conference of the series on which A. A. Karatsuba participated on the invitation of B. Novák. He later almost regularly participated on the conferences for what he always needed an official invitation. From Poland there were two particpants: W. Więsław and A. Mąkowski (Warsaw) 23.

There were 31 participants on the 1989 conference in Račková dolina including K. Dilcher (Halifax, Canada), P. Kiss (Eger, Hungary), E. Osmanagić (Sarajevo), A. Schinzel, W. Schwarz (Franfurt/Main), I. Sh. Slavutskiı̌ (Leningrad, today again St. Petersburg), A. Czogała, and K. Szymiczek 24

From the foreign participants let us mention that W. Schwarz had three lectures Spaces of arithmetical functions: An example to Gelfand's Theory, A new proof for a theorem connecting spaces of almost-periodical arithmetical functions, A new proof of a theorem of D. Wolke. I. Sh. Slavustkii had two ones Staudt's contribution to the theory of Bernoulli numbers and On a lower bound of the regulator of algebraic number fields. K. Dilcher lectured about Pi, Euler numbers, and asymptotic expansions (for more details consult [21]) and K. Szymiczek on Witt equivalence of global fields.

The 10th conference was the first after the collapse of the communism. The members of the organizing committee of this 1991 conference were $\breve{S}$. Porubský,

${ }^{23}$ A. Mąkowski grew up somewhere on the Polish-Slovak border, and therefore he had a very good command of Slovak language, what was a motivation for him to participate several times on the conferences, especially when they were organized on the Slovak territory.

${ }^{24}$ For the complete list see Math. Slovaca 41 (1991), no. 3, p. 249. 


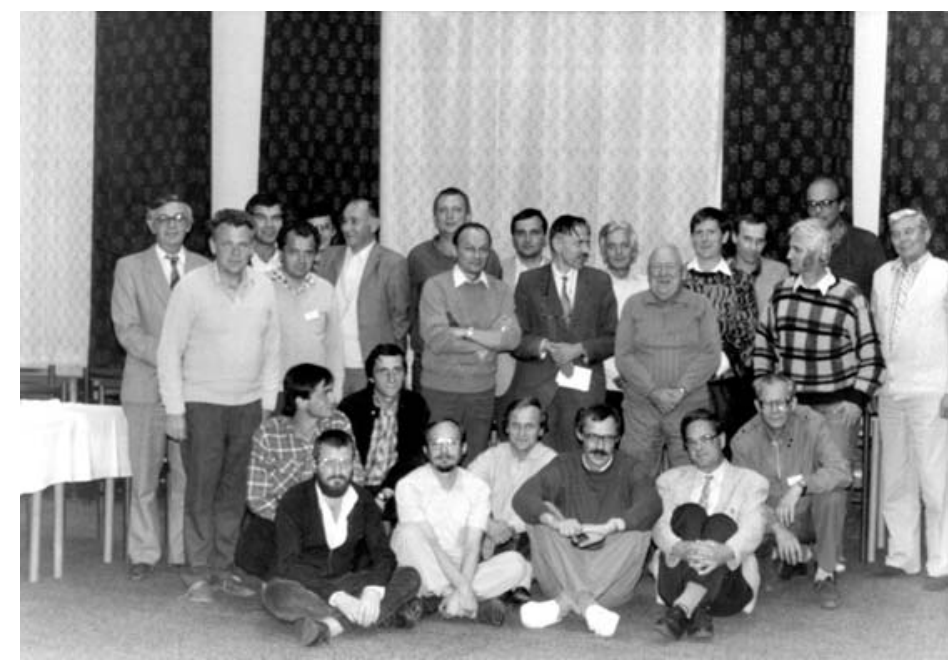

Figure 16. Family photo of the 9 th conference.

F. Marko, O. Strauch and L. Skula. By the way, this was the first conference of this series where it was possible to apply by the email (using the address porubsky@uvtef.uucp). Most foreign participants came from Austria. For instance, U. Dieter had a talk on The discrepancy of the sequence $\{n \alpha\}$ and extreme values of Dedekind sums, M. Drmota lectured On linear Diophantine equations and Fibonacci numbers, W. G. Nowak on Lattice points in large convex bodies, etc. For more information see Math. Slovaca 42 (1992), no. 5, 513-515.

The 11th conference was held for the last time (more exactly for the third time) in Račková dolina. For instance, A. Schinzel lectured here on the joint work with K. Gyôry under the title On a conjecture of Posner and Rumsey. K. Gyóry on Upper bounds for the degrees of decomposable forms of given discriminant, and K. Szymiczek on Graphs of Witt equivalence classes of quadratic extensions of a number field. For details on the 11th conference consult Math. Slovaca 44 (1994), no. 5 .

More than 50 participants had 32 talks at the 12 th conference and 10 from them can be found in Tatra Mt. Math. Publ. 11 (1997). The foreign participants were among others: A. Czogała, K. Dilcher, U. Dieter (Graz), M. Drmota (Vienna), K. Girstmair (Insbruck), P. Grabner (Graz), K. Győry, L. Hajdu (both Debrecen), A. A. Karatsuba, B. Klinger (Graz), J. Knopfmacher (Johannesburg), St. Louboutin (Caen), T. Metsänkylä (Turku), W. Narkiewicz, A. Schinzel, J. Schoißengeier (Vienna), M. Skałba (Warsaw), K. Szymiczek, J. M. Thuswaldner (Graz), R. F. Tichy (Graz), W. Więsław, R. Winkler (Vienna). 


\section{ŠTEFAN PORUBSKÝ}

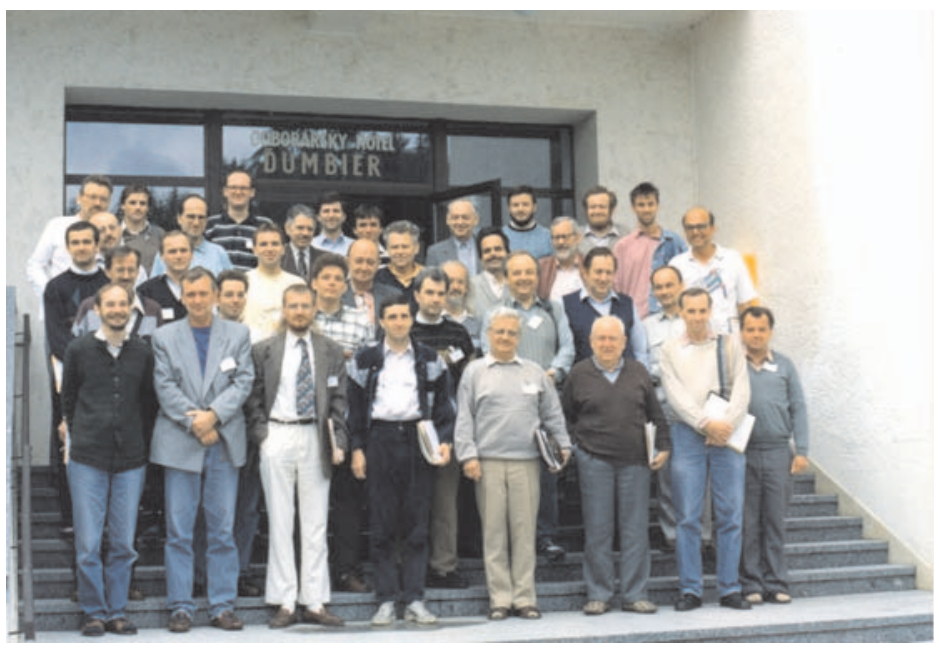

Figure 17. Family photo of the 12 th conference.

The details of the 13th conference can be found in Acta Mathematica et Informatica Universitas Ostraviensis 6 (1998), no. 1.

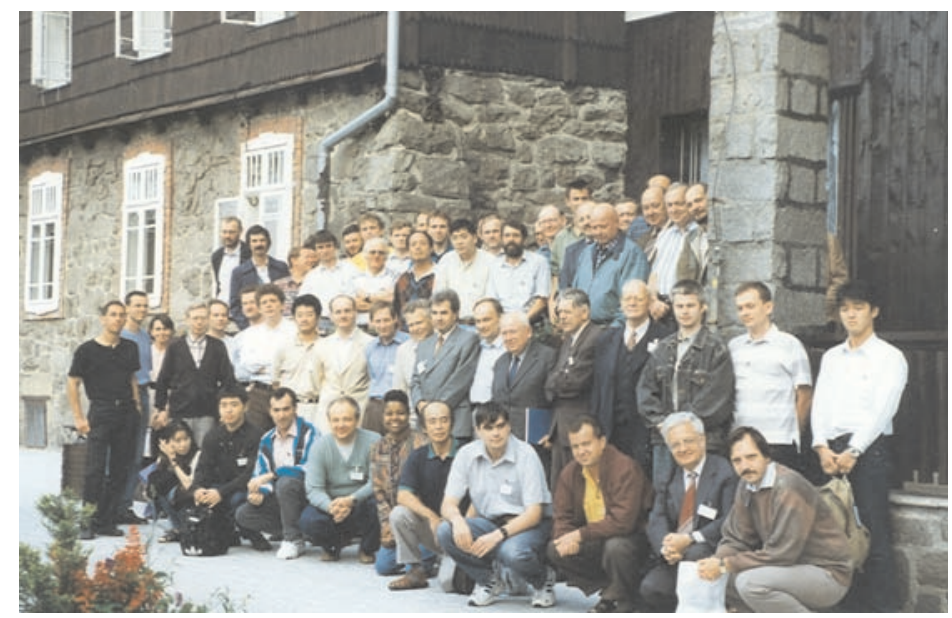

Figure 18. Family photo of the 13th conference.

Starting with 14th Czech and Slovak International Conference on Number Theory, Liptovský Ján the information on the particular conference can be found on the web site http://ntc.osu.cz/. 


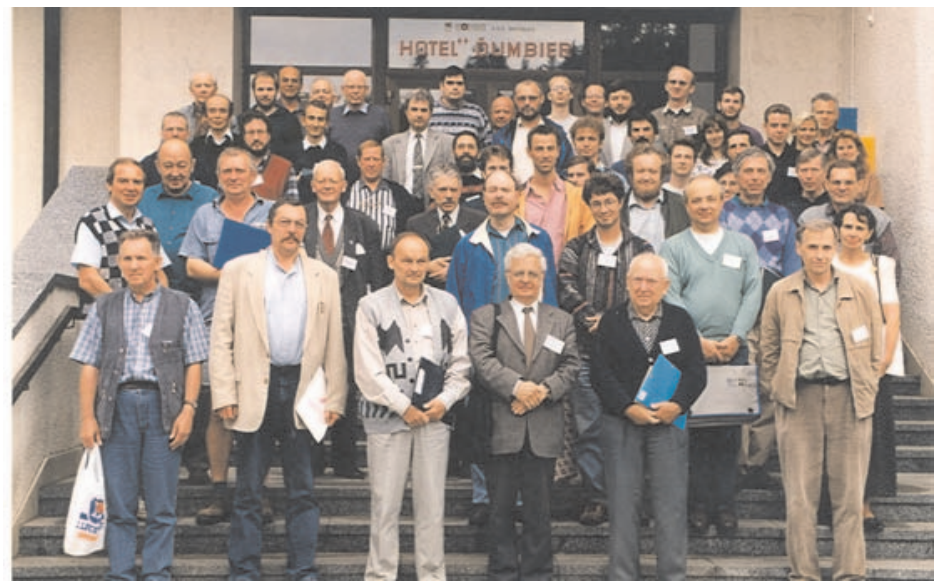

FiguRE 19. Family photo of the 14th conference.

In the first two decades most foreign participants came from Poland. After the collapse of communism among the foreign participants prevailed the Austrians. The last decade is characterized by a growing number of participants from Hungary forming currently the most numerous group.

The conferences on number theory have several direct or indirect offsprings.

On may 30, 1996 Juraj Kostra organized a miniconference Ostrava - Katowice on number theory in Ostrava supported by the so called Higher Education Development Fund (Fond rozvoje vysokých škol) of the Ministry of Education of the Czech Republic. Since the distance between Ostrava and Katowice is about $100 \mathrm{~km}$, and the contacts between both groups were very good, K. Szymiczek came with the idea to launch a new series of conferences as an extension of the cooperation agreement between the universities. They agreed to organized them every two years by either the University of Ostrava in Czech Republic, or by the University of Silesia in Katowice. The primary aim of this series was to create a forum for $\mathrm{PhD}$ students in both countries to speak under minimal pressure to an audience including leading experts in involved countries and also listen to the talks of those experts addressed to them. Also mutual contacts among the older participants in the three countries should be extended to their $\mathrm{PhD}$ students. The conferences were thought of as "local versions" of unrestricted Czech and Slovak international conferences where attendance of PhD students had to be marginalized. From this reason at the beginning there participated mostly the number theorists from Czech Republic, Poland, and Slovakia. Due to the closeness of the languages the talks were allowed also in Czech, Polish or Slovak. In 2004 the name of the conference was extended to Polish, Czech and Slovak Conference on Number Theory. Due to a growing number of guests 


\section{ŠTEFAN PORUBSKÝ}

from other countries the use of these languages was slowly reduced. The range of topics covered also expanded beyond what is usually considered as number theory. Since 2010 the name changed to Joint Conferences on Algebra, Logic and Number Theory (9th Colloquiumfest on Algebra and Logic), and it includes topics in quadratic forms, linear algebraic groups, K-theory, algebraic geometry and logic. The miniconference in 1996 was subsequently denoted as the first in the following series:25

- The 2nd Polish and Czech Conference on Number Theory, 16-18 June, 1998, Cieszyn, Poland,

- The 3rd Polish and Czech Conference on Number Theory, 11-16 June, 2000, Ostravice, Czech Republic,

- 4th Czech and Polish Conference on Number Theory, June 11-14, 2002, Cieszyn, Poland,

- 5th Polish, Slovak and Czech Conference on Number Theory, June 14-18, 2004, Terchová, Slovakia 26

- 6th Polish, Slovak and Czech Conference on Number Theory, Będlewo, June 13-16, 2006, Poland,

- 7th Polish, Slovak and Czech Conference on Number Theory, June 10-12, 2008, Ostravice, Czech Republic,

- ALaNT-Joint Conferences on Algebra, Logic and Number Theory (9th Colloquiumfest on Algebra and Logic and the 8th Polish, Slovak and Czech Conference on Number Theory), June 21-24, 2010, Bukowina Tatrzańska, Poland,

- ALaNT-Joint Conferences on Algebra, Logic and Number Theory (10th Colloquiumfest on Algebra and Logic and the 9th Polish, Slovak and Czech Conference on Number Theory), 11-14 June 2012, Ostravice (Hotel Sepetná), Czech Republic,

- ALaNT-Joint Conferences on Algebra, Logic and Number Theory (11th Colloquiumfest on Algebra and Logic and the 10th Polish, Slovak and Czech Conference on Number Theory), Będlewo, June 8-13 2014, Poland.

After an initiative of Otokar Grošek and Karol Nemoga they together with Štefan Porubský and Attila Pethó organized a crypto section at the 14th Czech and Slovak International Conference on Number Theory in Liptovský Ján. It was decided there that a new series of conferences devoted to cryptology will be launched. In 2001 the first conference of this series called TATRACRYPT '01 was organized on the same venue. Since then every year one conference of this

\footnotetext{
${ }^{25}$ The main organizer of the $2 \mathrm{nd}, 4$ th and 6 th conference was K. Szymiczek.

${ }^{26}$ For the proceedings of the conference see Tatra Mt. Math. Publ. 32 (2005).
} 


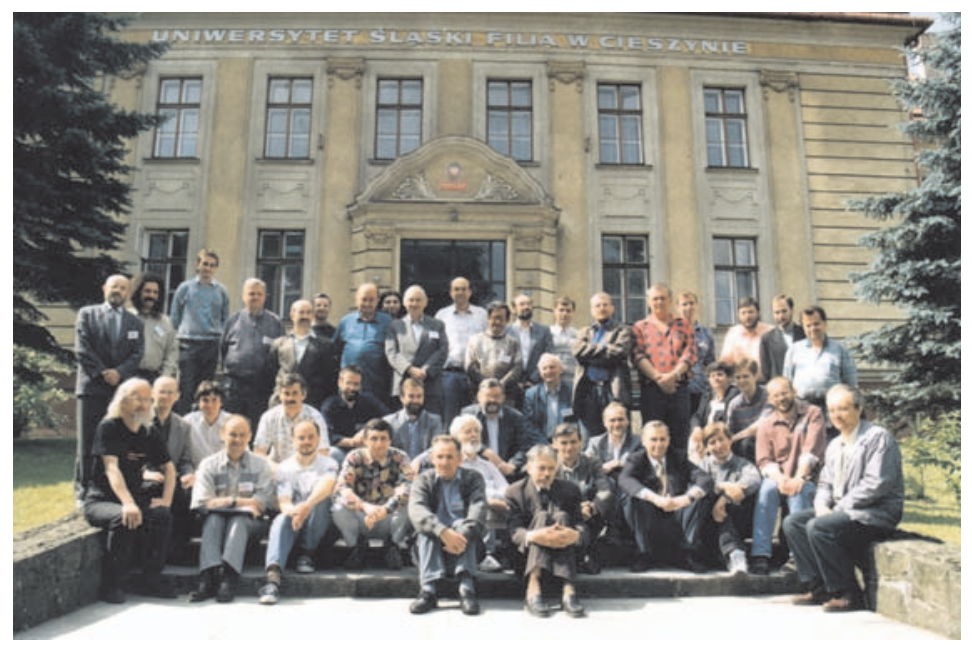

Figure 20. Family photo of the 2nd Polish and Czech conference.

series of Central European Conference on Cryptology was organized in countries of the Visegrád Group or in Austria.

Another series of conferences having partial roots in mathematical activities of organizers of the Czech and Slovak conferences on number theory are recently established conferences on uniform distribution:

- January 21-25, 2008, The 1st International Conference on Uniform Distribution Theory, CIRM, Marseille-Luminy, France (cf. [4] for more details),

- July 5-9, 2010, The 2nd International Conference on Uniform Distribution Theory, Strobl am Wolfgangsee, Austria (cf. [15] for more details),

- June 25-29, 2012, The 3rd International Conference on Uniform Distribution Theory, Congress Center of the Slovak Academy of Sciences, Smolenice, Slovakia (cf. [2] for more details),

- June 30-July 4, 2014, The 4th International Conference on Uniform Distribution Theory, Ostravice (Hotel Sepetná), Czech Republic.

Several from the mentioned persons and active participants of the seminar or conferences started their careers in Bratislava: J. Kostra (now at the University of Pardubice, Pardubice), J. Mináč (now at the University of Western Ontario, London), F. Marko (now at the Penn State, Hazleton), and also L. Mišík, and Š. Porubský. J. Tóth and M. Paštéka worked several years at the University of Ostrava.

To compile this paper would not have been possible without the substantial assistance of Ladislav Skula, Vojtech László, Oto Strauch, Kazimierz Szymiczek, 


\section{ŠTEFAN PORUBSKÝ}

Jaroslav Smítal, Juraj Kostra and others. Many of our colleagues with which we started this series of conferences are not more among us. To this sorrowful group belong I. Korec, K. Košuk, T. Šalát, Š. Znám (all Bratislava), Hanzalík (Trnava), B. Novák (Praha), J. Březina, K. Selucký (Brno), and M. Ciemała (Katowice).

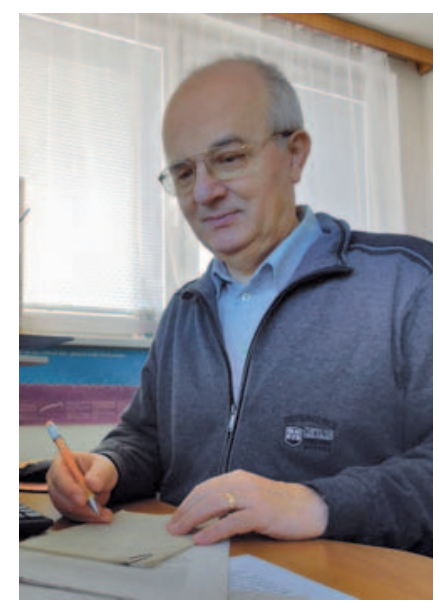

Figure 21. The author collecting the data for the paper.

\section{REFERENCES}

[1] Acta Fac. Rer. Nat. Univ. Comenianae. Math. 50-51, 1987/88.

[2] EDITORS: The Third International Conference on Uniform Distribution Theory-UDT2012, Smolenice, Slovakia, June 25-29 2012, Unif. Distrib. Theory 8 2013, no. 1, 1-6.

[3] ABRhAM, J.-ROSA, A.-SABIDUssi, G.-TURGEON, J.-M.: Anton Kotzig 19191991, Math. Slovaca 42 (1992), 381-383.

[4] EDITORS: International Conference on Uniform Distribution, Marseille, CIRM, January 21-25, 2008, Unif. Distrib. Theory, 3 no. 1 (2008), 1-8.

[5] BARBeAU, G. E. J.: Problem 179, Canad. Math. Bull. 14 (1971), p. 129.

[6] BRENTON, L.-VASILIU, A.: Znam's problem, Math. Mag. 75 (2002), 3-11.

[7] FIEDLER, M.: Reminiscences related to graph theory, Comput. Sci. Rev. 1 (2007), 65-66.

[8] KARATSUBA, A. A.-PORUBSKÝ, Š.-ROKYTA, M.-VLÁŠEK, Z.: Nedožité sedmdesátiny Prof. RNDr. Břetislava Nováka, DrSc. (1938-2003), [Unexpired seventies of Prof. RNDr. Břetislav Novák, DrSc. (1938-2003)], Pokroky matematiky, fyziky a astronomie 53 (2008), 53-58. (In Czech)

[9] KATRIŇÁK, T.: Professor Milan Kolibiar (1922-1994), Math. Slovaca 44 (1994), p. 489.

[10] KATRIŇÁK, T.: In memoriam: Milan Kolibiar (1922-1994), Order 12 (1995), 321-325.

[11] LÁSZLÓ, V.: On some problems in the elementary theory of numbers, Acta Fac. Rer. Nat. Univ. Comenianae, Math. 32 (1975), 47-67. 


\section{FOUR DECADES OF CZECH AND SLOVAK NUMBER THEORY CONFERENCES}

[12] MAREŠ, J.: Za profesorem Apfelbeckem, Pokroky matematiky, fyziky a astronomie 38 (1993), 239-240. (In Czech)

[13] MORDELL, L. J.: Systems of congruences, Canad. Math. Bull. 16 (1973), 457-462.

[14] NOVÁK, B.-SCHWARZ, Š.: Vojtěch Jarnık (22.12.1897-22.9.1970), Acta Arith. 20 (1972), 107-123.

[15] PILLICHSHAMMER, F.: Second international Conference on Uniform Distribution Theory, Strobl am Wolfgangsee, Austria, July 5-9 2010, Unif. Distrib. Theory 6 (2011), 1-7.

[16] PLESNÍK, J.-PORUBSKÝ, Š-ROSA, A.—ŠIRÁŇ, J.: Professor Štefan Znám (1936-1993), Math. Slovaca 44 (1994), 385-392.

[17] PORUBSKÝ, Š.: Leben und werk von Matyáš Lerch, in: Mathematik im Wandel, Vol. 2 (M. Toepell, ed.), DIV Verlag Franzbecker, Hildesheim Berlin, 2001, pp. 347-373.

[18] PORUBSKÝ, Š.: Matyáš Lerch (1860-1922). Šiauliai Math. Seminar 8 (2013), 197-222.

[19] RIEČAN, B.-ŠALÁT, T.: Professor Tibor Neubrunn (1929-1990), Math. Slovaca 41 (1991), 437-442.

[20] RIEČAN, B.: Štefan Schwarz (1914-1996), Czech. Math. J. 47 (1997), 375-382.

[21] SKULA, L. (ED.): Conference Report of the 9th Czechoslovak Colloquim on Number Theory, Račkova Dolina, The High Tatras, Czechoslovakia, 1989, Faculty of Sciences, Masarykova Universita, Brno, 1989, pp. 122.

[22] SKULA, L. (ED.): Summer School on Number Theory held at Chlébské, Rektorát UJEP, Brno, 1985, pp 102.

[23] SKULA, L.: On a problem of Znám, Acta Fac. Rer. Nat. Univ. Comenianae, Math. 32 (1975), 87-90.

[24] SZYMICZEK, K.: Ten problems on quadratic forms, Acta Math. Inform. Univ. Ostraviensis 10 (2002), 133-143.

[25] TOMASTA, P.: Obituary: RNDr. Juraj Bosák, DrSc., Math. Slovaca 37 (1987), 421-425. (In Slovak)

Received December 15, 2013

Institut of Computer Science

Academy of Sciences of the Czech Republic

Pod Vodárenskou věži 2

18207 Prague 8

CZECH REPUBLIC

E-mail: sporubsky@hotmail.com 